\title{
Prose Fiction and Early Modern Sexualities in England, 1570-1640
}




\section{Early Modern Cultural Studies}

Ivo Kamps, Series Editor

Published by Palgrave Macmillan

Idols of the Marketplace: Idolatry and Commodity Fetishism in English Literature, 1580-1680

by David Hawkes

Shakespeare among the Animals: Nature and Society in the Drama of Early Modern England

by Bruce Boehrer

Maps and Memory in Early Modern England: A Sense of Place

by Rhonda Lemke Sanford

Debating Gender in Early Modern England, 1500-1700

edited by Cristina Malcolmson and Mihoko Suzuki

Manhood and the Duel: Masculinity in Early Modern Drama and Culture by Jennifer A. Low

Burning Women: Widows, Witches, and Early Modern European Travelers in India

by Pompa Banerjee

England's Internal Colonies: Class, Capital, and the Literature of Early Modern English Colonialism

by Mark Netzloff

Turning Turk: English Theater and the Multicultural Mediterranean by Daniel Vitkus

Money and the Age of Shakespeare: Essays in New Economic Criticism edited by Linda Woodbridge 


\title{
Prose Fiction and Early MOdERN SEXUALITIES IN \\ ENGLAND, 1570-1640
}

\author{
Edited by
}

Constance C. Relihan

and

Goran V. Stanivukovic 


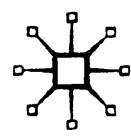

PROSE FICTION AND EARLY MODERN SEXUALITIES IN ENGLAND, 1570-1640

(C) Constance C. Relihan and Goran V. Stanivukovic 2003

Softcover reprint of the hardcover 1st edition 2003 978-1-4039-6388-8

All rights reserved. No part of this book may be used or reproduced in any manner whatsoever without written permission except in the case of brief quotations embodied in critical articles or reviews.

First published 2003 by

PALGRAVE MACMILLAN'M

175 Fifth Avenue, New York, N.Y. 10010 and

Houndmills, Basingstoke, Hampshire, England RG21 6XS

Companies and representatives throughout the world

PALGRAVE MACMILLAN is the global academic imprint of the Palgrave Macmillan division of St. Martin's Press, LLC and of Palgrave Macmillan Ltd. Macmillan ${ }^{\circledR}$ is a registered trademark in the United States, United Kingdom and other countries. Palgrave is a registered trademark in the European Union and other countries.

Library of Congress Cataloging-in-Publication Data

Prose fiction and early modern sexualities in England, 1570-1640 / edited by

Constance C. Relihan and Goran V. Stanivukovic

p. cm.-(Early modern cultural studies)

Includes bibliographical references and index.

ISBN 978-1-349-73216-6

ISBN 978-1-137-09177-2 (eBook)

DOI 10.1007/978-1-137-09177-2

1. English fiction-Early modern, 1500-1700-History and criticism.

2. Sex in literature. 3. Sex customs-England-History-16th century.

4. Sex customs-England-History-17th century. 5. Erotic stories,

English-History and criticism. I. Relihan, Constance Caroline.

II. Stanivukovic, Goran V. III. Series.

PR839.S49P76 2004

$823^{\prime} .3093538$-dc22

2003058080

A catalogue record for this book is available from the British Library.

Design by Newgen Imaging Systems (P) Ltd., Chennai, India.

First edition: January, 2004

$109876 \begin{array}{lllll}10 & 9 & 8 & 3 & 2\end{array}$

Transferred to Digital Printing 2011 
To Tom, Maeve, and Meg 



\section{O N T E N T S}

List of Illustrations

ix

Series Editor's Foreword $\quad \mathbf{x}$

Acknowledgments xii

List of Contributors xiii

Introduction: Prose Fiction and Early Modern Sexualities

in England, 1570-1640

Constance C. Relihan and Goran V. Stanivukovic

\section{PART I}

GENDER, GENRE, AND SEXUALITY

1 Love, Chastity and Woman's Erotic Power: Greek Romance in Elizabethan and Jacobean Contexts

Darlene C. Greenhalgh

2 "Dissordinate Desire" and the Construction of Geographic Otherness in the Early Modern Novella

Constance C. Reliban

3 Passion and Reason in Sir Philip Sidney's Arcadia

Lisa Hopkins

4 The Thigh and the Sword: Gender, Genre, and

Sexy Dressing in Sidney's New Arcadia

Steven Mentz

5 Prisoners of Love: Cross-Cultural and Supernatural Desires in Lady Mary Wroth's Urania

Sheila T. Cavanagh

PART II

\section{QUEER FICTIONS}

6 Same Difference: Homo and Allo in Lyly's Euphues Stephen Guy-Bray

7 Rogue-Sirens: Urban Seduction and the Collapse of Amicitia 
8 Gelding Gascoigne

Alan Stewart

9 "Knights in Armes": The Homoerotics of the English Renaissance Prose Romances

Goran V. Stanivukovic

\section{PART III}

\section{TEXTUALITY AND DESIRE}

10 Emasculating Romance: Historical Fiction in the Protectorate Elizabeth Sauer

11 Sidney, Gascoigne, and the "Bastard Poets" Robert W. Maslen

12 Unfolding the Shepherdess: A Revision of Pastoral

Lori Humphrey Newcomb

Afterword 


\section{I S T O F I L L U S T R A T I O N S}

1.1 Engraved frontispiece and sonnet from The Loves of Clitophon and Leucippe by Achilles Tatius and translated by Anthony Hodges, 1638. By permission of the Bodleian Library, University of Oxford, Douce T 206 (sig. Alv , A2)

9.1 The Golden Age in Metamorphoses Ovidii, Francoforti, 1563. The Newberry Library, Chicago (Case Y672. O 9456) 172

9.2 Collaert, A., after M. de Vos. America (Allegory).

Netherlandish, sixteenth-century engraving.

The Metropolitan Museum of Art, Estate of

James Hazen Hyde, 1959 (59.654.10) 


\section{S E R I E S E D I T O R'S F O R E W O R D}

Prose Fiction and Early Modern Sexualities in England, 1570-1640, is the first title in the Early Modern Cultural Studies Series that focuses explicitly and almost exclusively on representations of sexual thoughts, feelings, and practices. It does so in a way that reveals these thoughts, feelings, and practices to be culturally specific, and crucial in the production of human subjects as individuals. The study of early modern sexuality is of course not a new phenomenon, but Prose Fiction and Early Modern Sexualities makes a crucial contribution to this field of inquiry because it explores a genre - prose fiction that has hitherto been unfairly slighted in favor of the drama and poetry. As Constance C. Relihan and Goran V. Stanivukovic, the editors of Prose Fiction and Early Modern Sexualities, observe, "our picture of early modern sexualities will never be complete if we do not delve into the erotically rich narratives of early modern fiction." But Prose Fiction and Early Modern Sexualities does of course much more than merely study a neglected genre. Gathered here are essays dealing with constructions of "geographic otherness" in the early modern novella, "passion and reason" in Philip Sidney's Arcadia, the impact of Greek Romances on early modern conceptions of marriage, "sexy dressing" in Sidney's New Arcadia, "supernatural desires" in Mary Worth's Urania, "urban seductions" and homoerotic male bonding, print culture's "gelding" of Gascoigne, the undoing of sexual binaries in Lyly's Euphues, and, indeed, much more.

The word "sexualities" in this volume's title is deliberately used in its plural form, and the essayists assembled here - Darlene Greenhalgh, Lisa Hopkins, Steven Mentz, Sheila Cavanagh, Stephen Guy-Bray, Morgan Holmes, Alan Stewart, Elizabeth Sauer, Robert Maslen, and Lori Humphrey Newcomb - firmly underscore our suspicion that the early modern English never lived by a single, unified, dominant discourse of sexuality (with the grudging recognition that marginal individuals or small groups of individuals might gave practiced deviant behaviors). Indeed, what the examination of romances, novellas, translations of romances, and rogue literature points toward is that most of the representations of sexuality and desire in prose texts altogether defy the familiar traditional discourses of moderation and self-control. Exploring knightly romances, for instance, one contributor argues that the texts offer the early modern reader with a range of generally positive representations of same-sex erotic desire - representations that do not fit the traditional categories of "loyal friend and courting knight." 
What emerges most powerfully from Prose Fiction and Early Modern Sexualities is that discourses of sexuality are both amazingly varied and closely intertwined with other cultural discourses. Furthermore, influenced by the best tendencies of new historicism, the authors here allow for dynamic, reciprocal interaction between different cultural spheres, always refusing to explain sexualities in prose fiction in terms of other, seemingly more authoritative, discourses such as medical, political, or theological discourses, with which they may or may not coincide. Nor are they satisfied to understand sexualities within the generic constraints and conventions of the prose genre. In fact, because of prose fiction's marginal status in early modern culture, we can reasonably argue that its authors did not feel the same duty to color within the lines as did writers of a generically more strictly defined genre such as the drama or a more highly respected genre such as poetry. Intended to be read in private, the sprawling, non-narrative character of many prose fictions is in some ways the perfect vehicle for the exploration of, and experimentations with, sexualities without imposing on them the moral judgments, plot restrictions, and social condemnations that would be required of texts performed on the public stage or that aspired to the lofty name of poetry. No matter that scholarship today has unjustly snubbed this lively and thought-provoking genre, Prose Fiction and Early Modern Sexualities reminds us all just why the early modern multitudes were drawn so strongly to these texts: they dealt with sexuality in all its stimulating and breathtaking variety.

Ivo Kamps

Series editor 


\title{
A C K N O W L E D G M E N T S
}

\begin{abstract}
Work on this collection was completed with the help of a joint research fellowship from the South Central Modern Language Association and The Harry Ransom Humanities Research Center at the University of Texas at Austin. We are grateful to Lori Humphrey Newcomb for her scrupulous reading of the Introduction, to Natasha Hurley for her help in the final stages of our work on this collection, and to Ivo Kamps and Farideh-Koohi Kamali for their interest in this project. At Palgrave, Roee Raz and Ian Steinberg were helpful at every stage of the book's production. Our thanks go to V. S. Mukesh as well. In Austin, Nathan Abrams's wit and enthusiasm for arguments about the history and nature of sexuality were inspiring at every stage of the work on the Introduction. We are grateful to the Bodleian Library for the permission to reproduce the illustration in Darlene C. Greenhalgh's essay, and to the Newberry Library and The Metropolitan Museum of Art for permissions to reproduce figures in Goran Stanivukovic's essay.
\end{abstract}




\section{List of Contributors}

Stephen Guy-Bray is Assistant Professor of English at the University of British Columbia. He is the author of Homoerotic Space: The Poetics of Loss in Renaissance Literature (Toronto, 2002) and several articles, chiefly on Renaissance poetry and drama.

Sheila T. Cavanagh is Masse-Martin/NEH Distinguished Teaching Professor of English at Emory University. She is the author of Cherished Torment: The Emotional Geography of Lady Mary Wroth's Urania (Duquesne, 2001) and Wanton Eyes and Chaste Desires: Female Sexuality in The Faerie Queene (Indiana, 1994) and numerous articles on Renaissance literature and pedagogy. She is also the Director of Emory Women Writers Resource Project, a website devoted to women's writing from the sixteenth to twentieth centuries.

Darlene C. Greenhalgh received her undergraduate degree from University of California, Berkeley, in English and Comparative Literature, and is currently completing her doctorate on Hellenistic Romance in Sidney and Shakespeare at the University of Georgia. She presently lives in Oxford where she is the program coordinator for the University of Georgia student exchange program. She has published on Shakespeare.

Morgan Holmes is the author of Early Modern Metaphysical Literature: Custom and Strange Desires (Palgrave, 2001). He is the Director of Rochester Communications and teaches literature and cultural studies in the Division of Continuing Education at Ryerson University in Toronto.

Lisa Hopkins is Reader in English Literature at Sheffield Hallam University and editor of Early Modern Literary Studies. Her most recent publications are The Female Hero in English Renaissance Tragedy (Palgrave, 2002) and Writing Renaissance Queens: Texts by and about Elizabeth I and Mary, Queen of Scots (Delaware, 2002). She is currently working on Shakespeare on the $E d g e$, a study of Shakespeare's representation of the borders of early modern England, for Ashgate.

Lori Humphrey Newcomb is Associate Professor of English at the University of Illinois at Urbana-Champaign. Her study of Robert Greene's Pandosto and its many revisions, Reading Popular Romance in Early Modern England, was published by Columbia University Press in 2002. She is currently writing on print, performativity, and adaptation in plays by Greene and Shakespeare. 
Robert W. Maslen is Senior Lecturer in English Literature at the University of Glasgow. He has published a book, Elizabethan Fictions: Espionage, Counter-Espionage and the Duplicity of Fiction in Early Modern Prose Narratives (Clarendon, 1997), and editions of Sidney's Apology for Poetry (2002) and Dekker and Middleton's News from Gravesend (forthcoming), as well as essays on sixteenth-century prose, erotic narrative poetry, and drama. $\mathrm{He}$ is currently writing a book about Shakespearean comedy.

Steven Mentz is Assistant Professor of English at St. John's University. He has published several articles on English Renaissance prose fiction, including studies of Thomas Nashe, Philip Sidney, and Robert Greene. He is also coeditor of a collection of essays on the early modern rogue, forthcoming in 2004 from University of Michigan Press.

Constance C. Relihan is Hargis Professor of English Literature at Auburn University. She is the author of Fashioning Autbority: The Development of Elizabethan Novelistic Discourse (Kent State, 1994), Cosmographical Glasses: Geographic Discourse, Gender, and Elizabethan Fiction (Kent State, 2004), and editor of Framing Elizabethan Fictions: Contemporary Approaches to Early Modern Narrative Prose (Kent State, 1996).

Elizabeth Sauer is Professor of English at Brock University, where she holds a Chancellor's Chair for Research Excellence. She is the author of Barbarous Dissonance and Images of Voice in Milton's Epics (McGill-Queen's, 1996) and the just completed Paper-Protestations and Textual Communities in England, 1640-1675. She has also edited or coedited the following: Agonistics: Arenas of Creative Contest (with Janet Lungstrum, SUNY, 1997), Milton and the Imperial Vision (with Balachandra Rajan, Duquesne, 1999), winner of the Milton Society of America Irene Samuel Memorial Award; Books and Readers in Early Modern England: Material Studies (with Jennifer Andersen, Pennsylvania, 2002); Reading Early Women: Texts and Manuscripts in Print, 1550-1700 (with Helen Ostovich, Routledge, 2003); Literature and Religion in Early Modern England: Case Studies, Renaissance and Reformation (with Jennifer Andersen, 2004). Her work in submission includes Osiris and Urania: Milton and the Climates of Reading and Comparing Imperialism 1500-1900.

Goran V. Stanivukovic is Associate Professor of English at Saint Mary's University. He has published an edited collection, Ovid and the Renaissance Body (Toronto, 2001); a critical edition of Emanuel Ford's Ornatus and Artesia (Dovehouse Editions 2003) and essays on Shakespeare and Renaissance drama, nondramatic poetry, rhetoric, early modern queerness, and the Mediterranean. $\mathrm{He}$ is currently completing a book on prose romances, ethnography, and sexualities in early modern England, and is editing a volume of essays on the Mediterranean and early modern English literature and culture.

Alan Stewart is Professor of Renaissance Studies at Birkbeck College, University of London, and Associate Director of the AHRB Centre for 
Editing Lives and Letters. His publications include Close Readers: Humanism and Sodomy in Early Modern England (Princeton, 1997), Hostage to Fortune: The Trouble Life of Francis Bacon 1561-1626 (with Lisa Jardine; Victor Gollancz, 1998), Philip Sidney: A Double Life (Chatto \& Windus, 2000) and The Cradle King: A Life of James VI and I (Chatto \& Windus, 2003). He is currently editing volumes 1 and 2 of Bacon's Works for the new Oxford Francis Bacon. 